H.DOLP UND E.NETTO

\title{
GRUNDZÜGE \\ UND AUFGABEN DER DIFFERENTIAL- UND INTEGRALRECHNUNG \\ NEBST DEN RESULTATEN
}

22., verbesserte Auflage

VERLAG ALFRED TÖPELMANN, BERLIN W35

1955 